\title{
FARM SHELTER FOR EXPOSED ROLLING COUNTRY OF OTAGO
}

\author{
C. H. BROWN, Forester, New Zealand Forest Service, \\ Invercargill
}

Conditions of frequent cold south-westerly airstreams accompanied by gale force winds are a feature of the winter climate of Otago.

Growth of pasture is not checked to the same degree, stock do not lose condition, nor is the requirement for feed so great where effective shelter has been provided.

Factors which should be considered in the orientation and location of shelter belts in rolling country are discussed in this paper and suggestions made regarding tree species and shelter belt patterns most suited to the climatic and topographical features of the rolling country of Otago.

Conditions which effect the best orientation of shelter belts differ somewhat in South and West Otago from that in North and Central Otago. In both localities stock and pastures suffer most in winter from gale force south-west winds with driving hail, sleet, or snow.

In the south, however, rainfall is usually adequate over the summer and the warm drying north-west winds are of benefit by hastening the drying of pastures in spring and during haymaking in summer and autumn. The high temperatures which accompany north-west airstream conditions contribute to the fattening of lambs and growth of pasture.

In North Otago, however, drought conditions can brown off pastures early in summer. The demand of stock for water can bc severe.

The sun does not rise to any height at midday in midwinter in the most southern provinces of Southland and Otago. Trees will throw permanent shade to two and a half times their height in June and July. As most trees reach to over $60 \mathrm{ft}$, permanent shade to 3 chains to the south of trees must be expected.

\section{Value of Shelter Belts}

Tree shelter belts can ameliorate these climatic conditions and be of benefit in several ways. With all shelter, however, some advantage at one period of the year will be accompanied by a disadvantage at some other period. Shelter that benefits one crop or 
field use may prove disadvantageous when the field is rotated to another crop or use.

As trees may take 20 to 30 years to reach a height at which they give maximum benefit, the location and orientation should be carefully studied in relation to the most frequent use to which any particular field will be put or it may well be found that the disadvantages outweigh the advantages.

In North Otago one farmer has noted that in summer drought periods sheep have required 50 per cent less water in sheltered paddocks than in exposed paddocks and pastures have remained green for longer. This can be a great advantage where water is difficult to obtain, as it will be in drought periods.

In midwinter in the south and at altitudes of about $2,000 \mathrm{ft}$ above sea level in the north snowstorms may continue for several days and snow lie 6 to 12 in deep. Shelter catches the snow, leaving a strip one to two chains in width to the lee of the belts free of snow so that stock may continue to forage until the snow thaws.

Breeding ewes lose condition in these miserably cold storms. They may.walk before the wind until halted by a shelterless wire fence. They will, however, keep close to any shelter whether hedge, shelter belt, or earth bank. Under sheltered conditions they maintain body heat with less food intake. The U.S.A. Department of Agriculture has on record that on one ranch where a field was sheltered by willow and poplar growth 100 tons of hay will feed the cattle. On another ranch nearby in a field without shelter the same number of cattle require 125 to 150 tons of hay during the same feeding season.

In spring, pasture growth is earlier where sheltered, particularly on northern and western slopes. The period of feeding out can be considerably shortened if sufficient sheltered paddocks on this aspect are available.

Lambing in Otago is generally timed for mid-September. This is a month with a record of low rainfall and good sunshine hours.

In the four or so weeks over which lambing is spread, one or two south-west storms of short duration with hail or sleet may be expected. Heavy lamb losses occur in these periods if no shelter has been provided.

\section{Orientation and Location of Shelter Belts}

No factor is more important in planning a shelter belt than is direction. In general a north-south direction is best and will shelter from the two important north-west and south-west winds. Permanent shade in winter is then cast only at the ends of shelter belts and over no great area. Any departure from true north must 
increase the shade effect, but the winter sun will shine at some time or other on both sides of a shelter deviating as much as 20 " from this direction.

In the south the north-west winds tend to be beneficial, but the south-west wind is more severe than in the north, consequently a south-south-east direction should be considered. This direction will funnel the north-west winds with no loss in the beneficial effect.

In the north, however, shelter from the north-west wind must also be considered and an orientation closer to true north may be preferable. In Central Otago scattered trees to shade stock from the $90^{\circ}+$ temperature of direct sunlight should be established.

In all new subdivisions of paddocks it should be considered whether the new fence will one day be used to fence one side of a shelter belt. If this is likely, the best orientation should be adopted.

The positioning of shelter belts on hilly country presents some difficulty. The turbulence of wind in hills and gullies is well known. The wind direction should always be carefully checked on the ground during a blow. For ridges with axis north and south, belts on the western side should be spaced so that there will be about $100 \mathrm{ft}$ vertical interval between breaks. On short slopes this means a belt about half-way up separating the cultivable top slopes from the steeper bottom slopes. A wide belt in this location has the advantage that successive lines of trees provide bottom shelter even though opened underneath by stock.

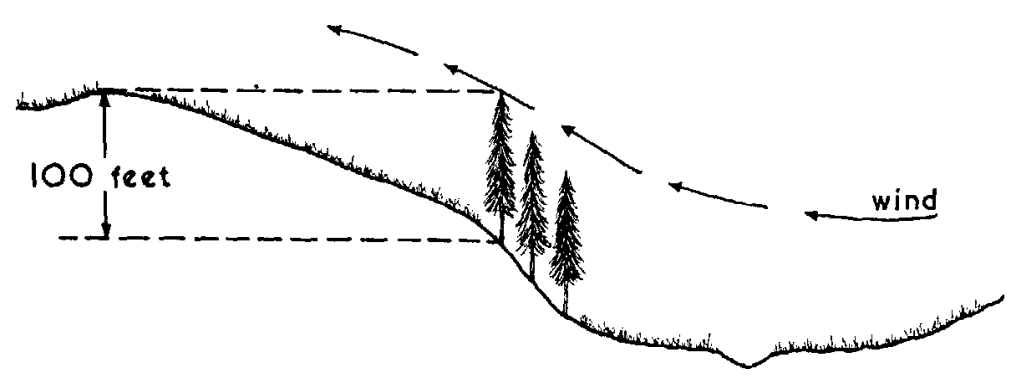

Fig. 1

With ridges and spurs with axis in an east-west direction, the problem is more difficult and the winds funnelling up the gullies more severe. Shelter belts must then be located running across the topography. 


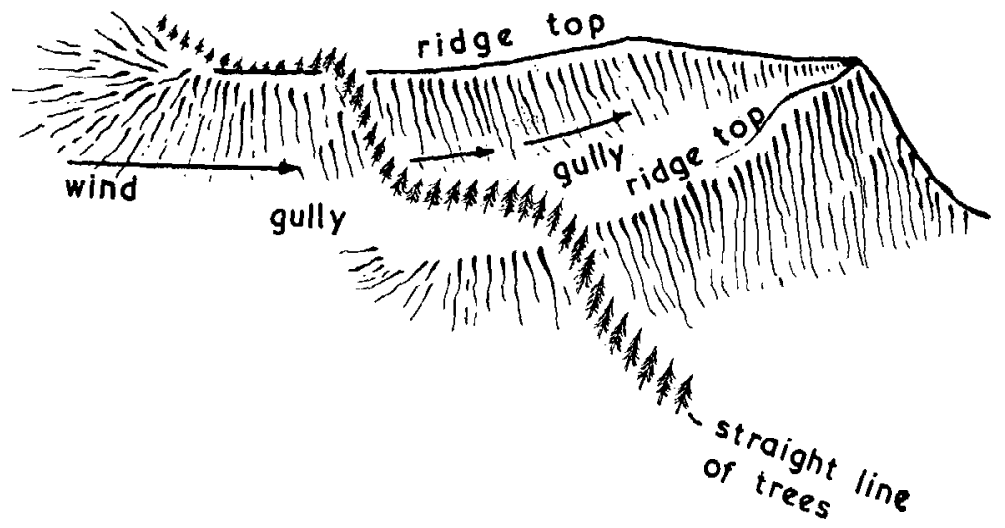

Fig. 2

\section{Shelter for Various Field Uses}

On most farms shelter is given priority in this order.

1. The homestead and farmyard.

2. The home and lambing paddocks.

3. Fields which may be cultivated.

4. Exposed fields.

5. Other fields.

There is a tendency to build the homestead on a high point on the farm. This may be fortuitous in that county roads are more readily built on the leading ridges. For safety reasons the women folk can keep an eye on lone workers. In cold weather stock may be supervised from the comfort of the home. Home paddocks will be well drained. Notwithstanding all these advantages the farmer must do most of his work in the farmyard and this will therefore be the first to be sheltered.

Trees are generally located to the west and south of the house and yard, but with an awareness of the danger of falling trees a 15 to $20 \mathrm{ft}$ high hedge of Cupressus macrocarpa or Pinus radiata is popular. These two species require annual trimming and frequent topping, however. This work can largely be avoided by using the slower growing conical shaped Lawson cypress or western red cedar.

The home and lambing paddocks are generally small and can be given good shelter by trees to the west. This shelter located 5 to 10 chins from the homestead may also supplement the hedge shelter. No building should be built within two chains of this shelter belt. Sooner or later an unexpected tree will fall on to a building and may destroy expensive equipment. A close, snug shelter is necessary for lambing paddocks. Lawson cypress is un- 
doubtedly the best type of tree, but where rapid growth is demanded trimmed macrocarpa and radiata pine may be substituted, but if not trimmed these trees will open out underneath, allowing a dangerous low draught to penetrate. In hilly country a north face of moderate slope should be chosen and shelter planted about half-way up the slope. Shelter in this location has these advantages:

1 , Least shade cast.

2. The wind will be lifted over the hill.

3. The maximum area of moderate slopes can be cultivated.

4. Often the trees can be located on the steepest parts which cannot be cultivated.

5. Even if the bases of the trees are open, successive rows of trees give low shelter.

6. Maximum warmth from the sun.

Hay paddocks should have shelter which takes into account the drying effect of the north-west winds and shelter should be located to funnel this wind. $\mathrm{P}$. radiata is probably the best shelter tree for hay paddocks because of the open nature of mature radiata pine belts and their ultimate height in excess of $100 \mathrm{ft}$. While there will be no complete shelter near the trees the effect will be a reduced wind velocity over a great area amounting to 50 per cent reduction in the south-west wind over 20 times the height of the trees, say 20 to 30 chains. In hilly country locations should be much as for the lambing paddock but need not be so intensive.

Where these paddocks may be used for lambing and stock holding over winter, belts of radiata pine and macrocarpa when first established should be trimmed as a hedge to $10 \mathrm{ft}$ or so. This portion will then remain green when the tree spreads above this height and will give good bottom shelter with no further trimming necessary. This advantage cannot be obtained by removal or cutting back of branches once the trees are older.

Ridge-top paddocks which are cultivated for turnips or seed crops. may require shelter to retard wind erosion of soil.

Other types of shelter which may be substituted for their aesthetic values are mixtures of Eucalyptus gigantea spaced at' $20 \mathrm{ft}$ with Lawson cypress or western red cedar planted at $\mathrm{S}$ ft intervals between, to be enlarged to IO ft by cutting out as the trees grow.

Deciduous trees such as Lombardy and other poplar's may be useful for shade in naturally sheltered valleys. The leaves are displayed in the hot summer when shade is beneficial and alternatively the leaves are absent in winter when shade would be harmful. As. "shelter for crops and fruit trees they are ideal, providing shelter when. the crops are ripening and most susceptible to wind 
damage, but as over-winter shelter for stock they are practically worthless.

\section{Siting of Shelter Belts}

Over the past extremely wet year many shelter belt trees have died. Deaths have been to all practical purposes confined to trees subjected to conditions of poor root aeration,

To maintain effective shelter belts of -vigorous, healthy trees the following rules should be observed:

1. Good permanent fencing at least $8 \mathrm{ft}$ out from the trees. Stock trampling and camping about the roots in wet years are the major cause of death in trees of all ages.

2. Never plant in soils subject to a widely fluctuating water table. Sites to be avoided are:
(a) alongside ditches
(b) lower slopes
(c) gully bottoms
(d) swampy ground.

Ridge tops and mid slopes are to be preferred.

3. Avoid frost hollows.

\section{Species Suitable for Shelter Belts in Otago}

Appendix I gives the various species which arc recommended, with the advantages and disadvantages of each and their expected height at 20 years of age. 
Av. Ht. at 20 yrs.

Species

Pinus rad

(radiata pine)

Cupressus

macrocarp

(macrocarpa)

Ch. lawsoniana

(Lawson cypress)

o Thuya plicata

(western red
cedar)

Eucalyptus gigantea

(Tasmanian ash)

Eucalyptus gunnii

(cedar gum)

Cupressus

(Arizona cypress)

Cedrus deodara

Cedrus deodara
(Himalayan cedar) of Age

60 to $80 \mathrm{ft}$

Advantages

Nursery stock is cheap, transplanting

with little loss. Rapid growth and dense

shelter while young.

40 to $50 \mathrm{ft}$ Dense shelter. Makes a good trimmed hedge.

20 to $25 \mathrm{ft}$

Transplants with little loss. Dense shelter throughout life. Long lived. Conical shape. No trimming to keep in shape. Transplants with little loss. Dense shelter throughout life. Long lived. Conical shape. Not subject to canker disease. Rapid growth while young. Moderately dense shelter. Not spreading. Seldom frosted.

40 to $50 \mathrm{ft}$

Rapid growth while young. Moderately dense shelter. Not spreading. Fairly Dense shelte

30 to $40 \mathrm{ft}$

20 to $25 \mathrm{ft}$

Transplants readily. Dense shelter. Suitable for dry climates.
Disadvantages

Mature belts are open and draughty underneath. Short

Spreading habit over $60 \mathrm{ft}$. Takes up a lot of land. Heavy losses in transplanting unless very

Slow growth. Subject to canker disease which may kill odd trees.

Slow growth.

Opens at bottom as trees mature Should be used only with other slow growing species such as Lawson cypress. Not easily transplanted.

Opens up as trees mature. Should be . Should be frost in inland localities. Difficult to transplant.

Slow growth. Spreading habit when mature. 


\section{DISCUSSION}

A. C. Hurst expressed concern about the disease which has affected pines in recent years and asked "what is it and what is the cure?"

A. There is no cure for the disease, A root rot (Phytophthora) is suspected and the primary cause appears to be waterlogging during the last wet year. Trees well fenced and well drained have not been affected.

Q. (R. Pinney): If all plantations have an expected life of 40 years what is the long term policy? Is there a forestry service to farmers similar to the service of the Agriculture Department?

A. A forestry service is available to farmers through local officers of the New Zealand Forest Service and in addition there is now an Extension Forest Service. Radiata pine in forestry is normally felled at 40 years but could last in shelter for 70 years. The Oregon pine rotation is 80 years and could be extended to 120 years which may give a timber more similar to the overseas product.

Q. (R. Pinney): Regarded 120 years as a short term and asked for suggested methods of replacement

A. Plans should be made for replacement of trees before they are mature. Further subdivision should also include plans for future plantings of trees. Radiata pine grown in conjunction with Lawsoniana can provide good shelter in 10-15 years.

Q. (-. Coulter): What is the actual value of a plantation in terms of increased stocking and timber in comparison with cost of establishment? How far back from a plantation can shelter be expected?

A. Value as timber depends on proximity to sawmill and quality. Trees in forestry may earn 7 to 8 per cent compound interest on cost of establishment, and those in shelter belts could be better if well cared for. Topping would ruin trees for timber purposes. As shelter, on the basis of an increase of 1 ewe per acre, which is probably excessive, cost of shelter could be recovered in two years.

At a distance from shelter of twenty times its height there can be a 50 per cent reduction in wind velocity. That is a $60 \mathrm{ft}$ high shelter belt would provide shelter for 20 chains approx.

R. Christie emphasised the important of preparation of pits prior to planting of trees and of not planting in areas subject to waterlogging. Also the importance of the medicinal value of poplar and willow in the control of bloat.

-. McKenzie raised the question of the value of D.D.T. to control grassgrub in establishing shelter plantings.

A. Grassgrub could be troublesome in nursery beds which should always be treated. Grassgrub is one cause of deaths in young trees. 